\title{
EPA panel recommends postponement of 2, 4, 5-T hearings
}

ThE herbicide $2,4,5-T$ poses no "substantial hazard to human helath or to the environment" according to a report prepared by the Scientific Advisory Panel of the section of the US Environmental Protection Agency concerned with the Federal Insecticide, Fungicide, and Rodenticide Act (FIFRA). Accordingly, the panel recommends that the final hearings to consider the validity of the ban on $2,4,5-\mathrm{T}$ be postponed until more information on the carcinogenicity and reproductive toxicity of the herbicide and its 2, 3, 7, 8-tetrachlorodibenzo-p-dioxin (dioxin) contaminant is available.

The EPA enforced a ban on the use of 2 , 4, 5-T in March of this year following a study in the state of Oregon which linked an increase of spontaneous abortions in the area to spraying with the herbicide (Nature $8 \mathrm{March}$, page 108). The initial ban was restricted to use of the herbicide in forestry but since then has been made total and applies to all applications of 2, 4, 5-T.

Law Court and EPA hearings have been held at intervals since March to consider the merits of the ban. The final hearings, initially scheduled for October 1979 have been postponed until January 1980 and if the advisory panel has its way will be postponed even longer.

The panel's report is based on evidence presented by interested parties at two open meetings held during the summer. Following the meetings, the panel agrees that the EPA is correct in stating that 2, 4, 5-T and dioxin are teratogens and fetotoxins. It also takes the EPA view that as dioxin is carcinogenic in test animals it may be a "potential human carcinogen."

But the panel disagrees with the EPA's opinion that human exposure "from spray drift and the water environment is likely to be broad or substantial" where 2, 4, 5-T use on rice is concerned. As for the use of the herbicide on rangeland the panel says there is no "convincing argument of an immediate or substantial hazard" to humans.

Dow Chemical Company is the major producer of 2, 4, 5-T in the US and stands at the forefront of the campaign to have the ban on 2, 4, 5-T lifted. The company insists that there is no good scientific evidence to

support the ban. Dow scientists admit that dioxin is extremely toxic but state that it is not present in sufficient concentrations to pose a human health hazard.

The Advisory Panel points out that on some questions the EPA position is "relatively close to that of the scientists from the Dow Chemical Company". In contrast to the view put forward by the EPA that there is no safe level for dioxin in rats and mice the panel says that such a statement is incorrect. And it suggests that a review of the evidence shows that the EPA and Dow Chemical are not as far apart on this issue as it might seem.

It remains to be seen whether this internal vetting process will have any influence on the EPA's actions on 2, 4, 5-T. The results of the report will give a considerable boost to Dow's campaign and the company for public relations reasons, may well agree with the final recommendations of the panel, that in view of the potential toxicity of dioxin "efforts should be made to further reduce" its level in commerical preparations of 2, 4, 5-T.

Alastair Hay

\section{Pathogens panel should have lay representation, says UK health minister}

THE new Conservative government, like its predecessor, is taking into account the recommendations of the Shooter Report on the outbreak of smallpox in Birmingham last year in drawing up new regulations for the safe handling of dangerous pathogens during research work and diagnosis. Mr Patrick Jenkin, Secretary of State for Health, told a meeting organised by the Association of Scientific, Technical and Managerial Staffs (ASTMS) in London last week, that the government is planning to implement many of the Shooter recommendations and also some of those made by the Health and Safety Executive in its recent publication 'Dangerous Pathogens: draft regulations and draft guidance notes'.

Under the government's new proposals, notification of intention to work with category A pathogens (the most dangerous) would be compulsory, said $\mathrm{Mr}$ Jenkin, and laboratories would have to be inpsected by HSE inspectors before work could begin. They would then have to be inspected regularly against a checklist which is to be drawn up in accordance with recommendations laid down by Shooter. Laboratories researching with category $\mathbf{A}$ pathogens would also have to be sited outside densely populated areas.

The government has set up a panel which is currently looking into the workings of the Dangerous Pathogens Advisory Group (DPAG), a committee of experts currently under the auspices of the Department of Health and Social Security (DHSS) which was set up in 1973 to administer a system of voluntary control of work with category $\mathbf{A}$ pathogens. According to $\mathrm{Mr}$ Jenkin, the panel is likely to recommend that a new body be set up with an expert and lay membership, including professional, trade union and public interest representatives. This body should remain under the aegis of the DHSS and would administer the new compulsory system of notification.

The position with public health laboratories is different because they are mainly concerned with category B pathogens which do not have to be notified to DPAG. There could come a time, however, said $\mathrm{Mr}$ Jenkin, when notification for category $B$ pathogens would also become compulsory. Nevertheless, he assured the meeting that it is still the government's intention to implement within three years the recommendations for improved safety in public health service laboratories laid out in the Howie report published last year. "It would inevitably cost the National Health Service a lot of money to bring all its labs up to the standard of the Howie report", he said, but the government thought that the $£ 7$ million (1978 prices) needed could be found.

Clive Jenkins, General Secretary of ASTMS, agreed with the opening up of membership of DPAG to non-experts. "Free standing committees of experts are things of the past", he said and added that a body along the same lines as the Genetic Manipulation Advisory Group (GMAG)

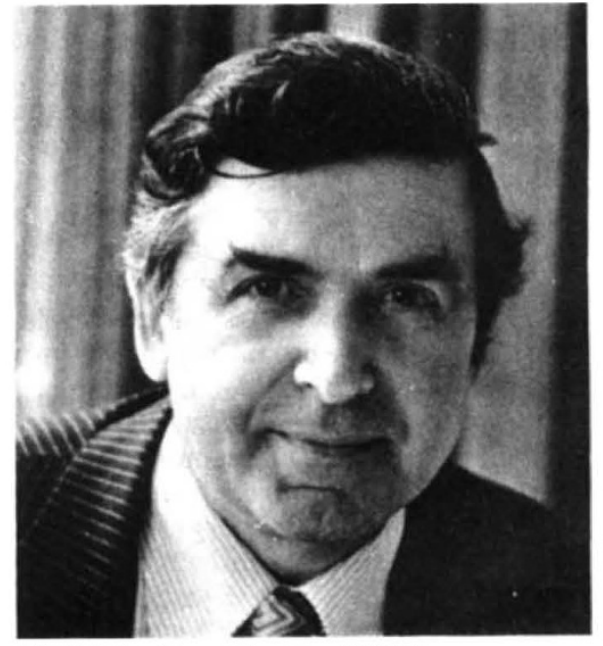

Patrick Jenkin: reforming DPAG

would be appropriate: "GMAG has worked as well as is possible for a voluntary body to work". Nevertheless he thought that the Health and Safety Executive would be a much more appropriate body than the DHSS to manage DPAG's affairs. "We want everyone to know the dangers of the leaky labs", he said.

Dr Roger Nourrish, microbiological inspector with the HSE, told the meeting of his visits to research and diagnostic laboratories designed to handle category $\mathrm{A}$ pathogens. Of the research laboratories, those at Reading and Paddington had stopped work before the HSE's visit, those at Purbright and Elstree were asked to stop work after the visit until improvements could be made and those at Porton Down and Liverpool were asked to make some inprovements while still remaining operational.

Judy Redfearn 